4. Foster Moore.-Trans. Ophthal. Soc. U.K., Vol. XXXII, p. 76, 1912.

5. - Brit.Jl. of Ophthal., p. 673, 1931.

6. - Proc. Roy. Soc. Med., March 10, 1933.

7. Trans. Ophthal. Soc. U.K., Vol. LIII, 1933.

8. KRUG and SAMUEL. - A rch. of Ophthal., pp. 871-879, December, 1932.

9. KuнN.-Amer.Jl. Ophthal., p. 427, 1931.

10. MCDONALD and LipPINCOTT.-Arch. of Ophthal., Vol. XX, No. 6, p. 958, December, 1938.

11. NicCOL and MOORE.-Brit. Jl. of Ophthal., p. 434, August, 1934.

12. SRINivaSAN.-Brit. Jl. of Ophthal., 1934.

13. Stallard.-Brit. Jl. of Ophthal. Monograph VI. Radiant Energy in Ophthalmic disorders, 1933.

14. Traquair.-Trans. Ophthal. Soc. U.K., Vol. LII, p. 311, 1932.

15 VAN DER Hoeve.-Trans. Ophthal. Soc. U.K., Vol. LII, p. 380, 1932.

16. VON HEMMES.-Groeningen. 1930.

17. WeVe, H. J. M.-Arch.f. Augenheilk., Vol. CX. Bd., 1937.

18. Wood, D. J.-Trans. Ophthal. Soc. U.K., Vol. XII, 1892.

\title{
ANNOTATION
}

\section{Eye Injuries in Air Raids}

Ophthalmology has been called the Cinderella of Medicine and Surgery, left alone to fend for herself, often with meagre accommodation and equipment, in a general hospital. On December 29, the night of the severest incendiary raid on London to date, Cinderella was much in evidence with the cinders and was very much occupied long after midnight. At one large eye hospital in the City, 280 corneal and conjunctival foreign bodies were removed from members of the Fire Services between midnight and $5.30 \mathrm{a} . \mathrm{m}$. Charred material formed the bulk of these foreign bodies. Most of the men had been attended to at First Aid Posts by the instillation of castor oil drops, had returned to their duties, been compelled to retire again on account of discomfort and then visited an eye surgeon. The first 100 to be treated all removed their pad and bandage on leaving the hospital to return to their duties of firefighting and so for the remainder this therapeutic refinement was dispensed with, thus affording a saving of time and material. The eye injuries caused by flying glass have been severe and on one night at a general hospital in the City the eye surgeon operated from 8 p.m. to 5.30 a.m. There were three cases in which both eyes were penetrated by splinters of glass, the most tragic being a husband and wife. Eyes containing glass fragments shrink relatively quickly, save in a few exceptional cases where a glass fragment has been retained in the vitreous for years without complications.

It is difficult enough to persuade industrial workers to adopt devices for their ocular protection and likewise it seems that firemen 
and soldiers become irritated by any addition to their accoutrement and as the severity of their task increases they cast away all but what they consider essential, preferring to take risks. To those less actively engaged in air raid duties but whose presence is necessary in look-out posts and on patrols, a pair of glasses fitted with one of the kinds of safety glass would save a number of eyes from destruction. To those sheltering in houses the pasting of windows with net, their occlusion by wooden shutters and the advice to keep clear of windows should be of sufficient prophylactic value.

\section{ABSTRACTS}

\section{I. - CONJUNCTIVA}

(1) Appelmans, M. (Louvain).-Parinaud's conjunctivitis caused by the virus of lymphogranulomatosis inguinale. (Conjonctivite infectieuse de Parinaud causée par le virus de la maladie de Nicolas-Favre). Ophthalmologica, Vol. XCVI, p. $321,1939$.

(1) Appelmans recalls a case of Parinaud's conjunctivitis due to the virus of lymphogranulomatosis inguinale. The patient was a physician who had been accidently infected by this virus during experimental work and the ocular lesion constituted the essential feature in the affection.

ARNOLD SORSBY.

(2) Sysi, R. (Helsinki). - Treatment of gonococcal ophthalmia with $M$ and $B$ 693. (Ueber die Behandlung der Conjunctivitis gonorrhoica mit dem Präparet $\mathrm{M}$ and B 693). Acta Ophthalmologica, Vol. XVII, p. 466, 1939.

(2) Sysi gives details of 11 cases treated with M \& B 693 amongst other measures and stresses the value of this drug.

\section{ARNOLD SORSBY.}

(3) Vollaro (Milan).-A new method of treating inveterate pannus by diathermy-coagulation. (Di un tecnica personale di diatermo-coagulazione nella cura di panno corneale tracomatoso inveterato). Rass. Ital. di Ottal.. November-December, 1939.

(3) Vollaro quotes the use of diathermy in the treatment of pannus by several authors and explains why he has found it advisable to follow a different procedure. He fears that the 